\title{
ANALISIS KESTABILAN MODEL DISKRIT EKO-EPIDEMIOLOGI
}

\author{
Ani Salamah ${ }^{1}$, Novianita Achmad ${ }^{2}$, Nurwan ${ }^{3}$ \\ 1,2,3 Program Studi Matematika FMIPA, Universitas Negeri Gorontalo \\ email korespondensi : ani.mathung@gmail.com
}

Diterima : (25-09-2020), Revisi: (13-11-2020), Diterbitkan : (24-12-2020)

\begin{abstract}
ABSTRAK
Penelitian ini membahas tentang model diskrit eko-epidemiologi. Model eko-epidemiologi adalah gabungan dari ilmu ekologi dan epidemiologi yang membahas tentang interaksi antara predator, prey rentan, dan prey terinfeksi menggunakan fungsi respon Holling tipe I dan pertumbuhan prey rentan mengunakan fungsi logistik untuk membatasi pertumbuhan yang berlebihan pada prey rentan.Model diskrit eko-epidemiologi diperoleh dengan mendiskritisasikan model eko-epidemiologi menggunakan metode Euler. Dari model diskrit tersebut diperoleh 5 titik kesetimbangan, yaitu titik kesetimbangan $E_{0}$ dimana semua populasi mengalami kepunahan, titik kesetimbangan $E_{1}$ ketika terjadi kepunahan pada populasi prey terinfeksi dan predator, titik kesetimbangan $E_{2}$ ketika terjadi kepunahan pada populasi prey terinfeksi, titik kesetimbangan $E_{3}$ ketika terjadi kepunahan pada populasi predator, dan titik kesetimbangan $E_{4}$ ketika semua populasi hidup berdampingan. Berdasarkan hasil analisisnya, $E_{0}$ selalu tidak stabil, hal ini disebabkan oleh nilai eigen yang diperoleh pada persamaan linierisasi model di sekitar titik-titik ekuilibrium tersebut, nilai mutlaknya selalu besar satu. Untuk $E_{1}, E_{2}, E_{3}$, dan $E_{4}$ kestabilan titik-titik kesetimbanganditentukan oleh suatau syarat dan kondisi tertentu .
\end{abstract}

Kata kunci : model eko-epidemiologi, model diskrit, analisis kestabilan 


\begin{abstract}
This study discusses a discrete eco-epidemiological model. The eco-epidemiological model (the combination of ecology and epidemiology) that discusses the interaction between predator and prey as well as the spread of disease in it. The interaction employed the Holling response function type I, while the growth of susceptible prey relied on a logistic function to limit overgrowth in susceptible prey. A discrete eco-epidemiological model was obtained by discretizing the model using the Euler method, in which five equilibrium point were obtained: the equilibrium point $E_{0}$ (all populations experience extinction), the equilibrium point $E_{1}$ (the extinction occurs in infected and predator populations), the equilibrium point $E_{2}$ (the extinction occurs in the prey infected population), the equilibrium point $E_{3}$ (the extinction occurs in a predator population), and the equilibrium point $E_{4}$ (all populations coexist). Based on the results of analysis, $E_{0}$ always unstable. This is due to the eigenvalues obtained in the model linearization equation around the equilibrium points, the absolute value is always large 1. For $E_{1}, E_{2}, E_{3}$, dan $E_{4}$, the stability of the equilibrium points is determined by certain terms and conditions.
\end{abstract}

Key words : eco-epidemiology model, discrete model, stability analysis

\title{
Pendahuluan
}

Model eko-epidemiologi merupakan model interaksi antara predator dan prey dengan adanya penyebaran penyakit pada populasi tertentu. Dimana interaksi antara predator dan prey dibahas dalam bidang ilmu ekologi, sedangkan penyebaran penyakit pada populasi dijelaskan oleh bidang ilmu epidemiologi.

Model predator-prey pertama kali diusulkan oleh Lotka-Volterra pada tahun 1920-1926 yang menjelaskan tentang model pertumbuhan populasi dua spesies. Perkembangan selanjutnya yaitu dengan memodifikasi model predator-prey Lotka-Voltera dengan menambahkan fungsi logistik pada populasi prey, dimana populasi tersebut tidak akan bertumbuh melewati batas pertumbuhan populasi yang sudah ditentukan. Model ini dikenal dengan model predator-prey Gause. Selain menambahkan fungsi logistik pada model, penambahan fungsi respon juga dilakukan untuk membatasi laju predasi oleh predator (Murray, 2002).

Untuk penyebaran penyakit, Kermack dan MacKendrick pada tahun 1927 dan 1832 mengusulkan model matematika epidemik yang lebih maju yaitu model SIR yang banyak digunakan saat ini (Brauer dan Castillo-Chavez, 2012). Model SIR ini dapat dimodifikasi menjadi model SI dengan asumsi bahwa populasi yang terserang penyakit tidak akan bisa sembuh. 
Penelitian terkait ekologi dan epidemiologi berkembang secara terus menerus, sehingga terdapat penelitian baru yang menggabungkan kedua penilitian tersebut yang dinamakan model eko-epidemiologi. Model eko-epidemiologi membahas tentang model predator-prey dan penyebaran penyakit yang terjadi saat pemangsaan. Beberapa penelitian terkait model ini adalah Xiao dan Chen (2002), Purnomo, dkk. (2017), Siddik (2017), Hasan, dkk. (2020), Arsyad, dkk. (2020) dan Maisaroh, dkk. (2020).

Penelitian yang lainnya juga melakukan modifikasi dengan merubah model kontinu menjadi model diskrit untuk melihat apakah ada perbedaan dari model tersebut. Modifikasi model dilakukan dengan mendiskritisasi model menggunakan metode Euler. Beberapa penelitian terkait model diskrit adalah penelitian Raj, dkk. (2013), Hu, dkk. (2014), Munandar (2017), dan Mokodompit, dkk. (2020). Sehingga pada artikel ini akan membahas tentang analisis kestabilan model diskrit eko-epidemiologi.

\section{Metode Penelitian}

Tahapan dalam penelitian ini adalah penelusuran buku, jurnal, artikel, maupun text-book yang berhubungan dengan penelitian, menentukkan asumsi untuk membentuk model eko-epidemiologi, memodifikasi model menggunakan metode Euler untuk memperoleh model diskrit eko-epidemiologi, menentukkan titik kesetimbangan model diskrit eko-epidemiologi dan menganalisisnya.

\section{Hasil dan Pembahasan}

Dalam bab ini akan diperoleh model matematika eko-epidemiologi, model diskriteko-epidemiologi, titik kesetimbangan, dan analisis kestabilan dari titik.

\section{Model Matematika}

Model yang digunakan adalah model predator-prey Gause dengan fungsi respon Holling tipe I dan prey yang terserang penyakit. Dengan asumsi bahwa populasi prey bertumbuh secara logistik yang dipengaruhi oleh daya dukung lingkungan hidup populasi, populasi predator terhadap prey menggunakan fungsi respon Holling tipe I dimana tidak ada perlawanan oleh prey dan populasi prey yang terserang penyakit tidak akan bisa sembuh. Sehingga diperoleh model matematika dalam bentuk sistem persamaan diferensial sebagai berikut. 


$$
\begin{aligned}
d S / d t \quad=r S(1 & -(S+I) / K)-\beta S I-a S Y \\
d I / d t & =\beta S I-b I Y-\alpha I \\
d Y / d t & =c S Y+d I Y-\delta Y
\end{aligned}
$$

Dengan $r, K, \alpha, \beta, \delta, a, b, c, d>0 . S$ menyatakan populasi prey rentan, I menyatakan populasi prey terinfeksi, $Y$ menyatakan populasi predator, $r$ adalah pertumbuhan intrinsik populasi prey, $K$ adalah daya dukung lingkungan populasi, $\alpha$ adalah laju kematian prey terinfeksi, $\beta$ adalah koefisien penyebaran penyakit, $\delta$ adalah laju kematian predator, $a$ adalah laju pemangsaan predator terhadap prey rentan, $b$ adalah pemangsaan predator terhadap prey terinfeksi, $c$ adalah jumlah populasi predator yang masuk akibat memangsa prey rentan, dan $d$ adalah jumlah populasi predator yang masuk akibat memangsa prey terinfeksi.

Dari model matematika diatas, selanjutnya didiskritisasi menggunakan metode Euler (Elaydi, 2007). Misalkan pada persamaan (1) variabel waktu $t$ dibatasi pada selang $(0, T)$, maka diskritisasi model (1) dilakukan dengan membagi selang $(0, T)$ menjadi $N$ subselang yang sama dengan lebar $h=t_{n}-t_{n-1}$. Diperoleh $N+1$ titik dengan $t_{n}=n h, n=0,1,2, \ldots, N$. Sehingga diperoleh model diskrit eko-epidemiologi sebagai berikut.

$$
\begin{gathered}
S(n+1)=S(n)+h[r S(n)(1-(S(n)+I(n)) / K)-\beta S(n) I(n)-a S(n) Y(n)] \\
I(n+1)=I(n)+h[\beta S(n) I(n)-b I(n) Y(n)-\alpha I(n)] \\
Y(n+1)=Y(n)+h[c S(n) Y(n)+d I(n) Y(n)-\delta Y(n)]
\end{gathered}
$$

Dimana $S(n)$ merupakan kepadatan populasi prey rentan, $I(n)$ merupakan kepadatan populasi prey terinfeksi, $Y(n)$ merupakan kepadatan populasi predator dan parameter $h$ merupakan ukuran langkah.

\section{Titik Kesetimbangan}

Menurut definisi titik kesetimbangan (Elaydi, 2007), suatu titik $x^{*}$ dikatakan titik kesetimbangan dari fungsi $f$ jika memenuhi persamaan $f\left(x^{*}\right)=x^{*}$ dan $x^{*}$ merupakan solusi konstan. Sehingga titik kesetimbangan model diskrit eko-epidemiologi diperoleh dengan menyelesaikan persamaan berikut.

$$
\begin{gathered}
S=S+h[r S(1-(S+I) / K)-\beta S I-a S Y] \\
I=I+h[\beta S I-b I Y-\alpha I] \\
Y=Y+h[c S Y+d I Y-\delta Y]
\end{gathered}
$$

Dari ketiga persamaan tersebut diperoleh

$$
S=0 \text { atau } r S\left(1-\frac{S+I}{K}\right)-\beta S I-a S Y=0
$$




$$
\begin{gathered}
I=0 \text { atau } \beta S I-b I Y-\alpha I=0 \\
Y=0 \text { atau } c S Y+d I Y-\delta Y=0
\end{gathered}
$$

Titik kesetimbangan persamaan (2) diperoleh dari kombinasi persamaan (4), (5), dan (6), yaitu:

1. $E_{0}=(0,0,0)$. Titik kesetimbangan $E_{0}$ dapat disebut sebagai titik kepunahan predator dan prey.

2. $E_{1}=(K, 0,0)$. Titik kesetimbangan $E_{1}$ dapat disebut sebagai titik kepunahan predator dan prey terinfeksi.

3. $E_{2}=\left(\frac{\delta}{c}, 0, \frac{r(K c-\delta)}{K a c}\right)$ dengan $\delta<K c$. Titik kesetimbangan $E_{2}$ dapat disebut sebagai titik kepunahan prey terinfeksi.

4. $E_{3}=\left(\frac{\alpha}{\beta}, \frac{r(K \beta-\alpha)}{\beta(K \beta+r)}, 0\right)$ dengan $\alpha<K \beta$. Titik kesetimbangan $E_{3}$ dapat disebut sebagai titik kepunahan predator.

5. $E_{4}=\left(x, \frac{\delta-c x}{d}, \frac{\beta x-\alpha}{b}\right)$ dengan $x=\frac{r b(\delta-K d)+K(\beta \delta b-\alpha a d)}{r b(c-d)+K \beta(c b-a d)}$. Titik kesetimbangan $E_{4}$ dapat disebut sebagai titik keberhasilan hidup ketiga populasi atau titik ko-eksistensi dengan syarat $x \geq 0$ dengan $\delta>K d, b \beta \delta>a d, c>$ $d, b c d>a b d$.

\section{Analisis Kestabilan}

Untuk mempelajari dinamika model disekitar $E_{0}, E_{1}, E_{2}, E_{3}$, dan $E_{4}$ terlebih dahulu dicari persamaan linierisasi dari persamaan (2). Untuk melinierkan suatu persamaan maka dibuatlah matriks jacobian $\left(J_{E}\right)$ sebagaimana pada Munandar (2017) berikut ini.

$$
J_{E}=\left[\begin{array}{lll}
a_{11} & a_{12} & a_{13} \\
a_{21} & a_{22} & a_{23} \\
a_{31} & a_{32} & a_{33}
\end{array}\right]
$$

Dengan $\quad a_{11}=1+h r-\frac{2 h r}{K} S-\frac{h r}{K} I-h \beta I-h a Y, a_{12}=-\frac{h r S}{K}-h \beta, a_{13}=$ $-h a S, a_{21}=h \beta I, a_{22}=1+h \beta S-h b Y-h \alpha, a_{23}=-h b I, a_{31}=h c Y, a_{32}=$ $h d Y, a_{33}=1+h c S+h d I-h \delta$. Matriks Jacobian tersebut akan digunakan untuk menganalisis setiap titik kesetimbangan dengan mencari nilai eigen $(\lambda)$ yang diperoleh dari menyelesaikan persamaan kerakteristik $\operatorname{det}\left(\lambda I-J_{E}\right)=0$. Analisis titik kesetimbangan dilakukan dengan cara mensubtitusi setiap nilai titik kesetimbangan ke dalam matriks Jacobian tersebut. Untuk menentukan kestabilan titik 
kesetimbangan dari model diskrit, dapat digunakan definisi dan lemma berikut.

Definisi. Misalkan ada tiga nilai eigen yaitu $\lambda_{1}, \lambda_{2}$ dan $\lambda_{3}$, dikatakan stabil jika :

1. $\left|\lambda_{1}\right|<1,\left|\lambda_{2}\right|<1$, dan $\left|\lambda_{3}\right|<1$, maka titik kesetimbangan dari $E\left(x^{*}, y^{*}, z^{*}\right)$ disebut silk atau stabil lokal asimtotik.

2. $\left|\lambda_{1}\right|>1,\left|\lambda_{2}\right|>1$, dan $\left|\lambda_{3}\right|>1$, maka titik kesetimbangan dari $E\left(x^{*}, y^{*}, z^{*}\right)$ disebut source dan tidak stabil.

3. $\left|\lambda_{1}\right|>1,\left|\lambda_{2}\right|>1$, dan $\left|\lambda_{3}\right|<1$ atau $\left|\lambda_{1}\right|<1,\left|\lambda_{2}\right|>1$, dan $\left|\lambda_{3}\right|>1$, maka titik kesetimbangan dari $E\left(x^{*}, y^{*}, z^{*}\right)$ disebut saddle dan tidak stabil.

4. $\left|\lambda_{1}\right|=1,\left|\lambda_{2}\right|=1$, dan $\left|\lambda_{3}\right|=1$, maka titik kesetimbangan dari $E\left(x^{*}, y^{*}, z^{*}\right)$ disebut non-hyperbolic.

(Hu, dkk., 2017)

Lemma 1. Diberikan $F(\lambda)=\lambda^{2}+B \lambda+C$, dimana $B$ dan $C$ konstanta. Jika $F(\lambda)>0$ dan $\lambda_{1}, \lambda_{2}$ adalah dua akar dari $F(\lambda)=0$, maka

1. $\left|\lambda_{1}\right|<1$ dan $\left|\lambda_{2}\right|<1$, jika dan hanya jika $F(-1)>0$ dan $C<1$;

2. $\lambda_{1}=-1$ dan $\left|\lambda_{2}\right| \neq 1$ jika dan hanya jika $F(-1)=0$ dan $B \neq 0,2$;

3. $\left|\lambda_{1}\right|<1$ dan $\left|\lambda_{2}\right|>1$, jika dan hanyajika $F(-1)<0$;

4. $\left|\lambda_{1}\right|>1$ dan $\left|\lambda_{2}\right|>1$, jika dan hanya jika $F(-1)>0$ dan $C>1$;

5. $\lambda_{1}$ dan $\lambda_{2}$ adalah akar konjuget kompleks dan $\left|\lambda_{1}\right|=\left|\lambda_{2}\right|=1$ jika dan hanya jika $B^{2}-4 A C<0$ dan $C=1$.

(Hu, dkk., 2014)

Lemma 2. Diberikan suatu persamaan $x^{3}+b x^{2}+c x+d=0$, dimana $b, c, d \in R$. Dengan $A=b^{2}-3 a c, B=b c-9 d, C=c^{2}-3 b d$,dan $\Delta=B^{2}-4 A C$. Maka

1. Persamaan memiliki 3 akar karakteristik yang berbeda jika dan hanya jika $\Delta \leq 0$.

2. Persamaan memiliki satu akar bilangan real dan sepasang akar konjuget kompleks jika dan hanyajika $\Delta>0$. Dengan akar konjuget kompleks

$$
\lambda=\frac{-2 b+Y_{1}^{\frac{1}{3}}+Y_{2}^{\frac{1}{3}}}{6} \pm i \frac{\sqrt{3}\left(Y_{1}^{\frac{1}{3}}+Y_{2}^{\frac{1}{3}}\right)}{6} \operatorname{dimana} Y_{12}=b A+\frac{-B \pm \sqrt{B^{2}-4 A C}}{2} .
$$

(Hu, dkk., 2014)

Sekarang dibahas analisis kestabilan dari titik kesetimbangan $E_{0}, E_{1}, E_{2}, E_{3}$, dan $E_{4}$. Untuk titik kesetimbangan $E_{0}=(0,0,0)$, matriks Jacobian dari persamaan (2) adalah 


$$
J_{E 0}=\left[\begin{array}{ccc}
1+h r & 0 & 0 \\
0 & 1-h \alpha & 0 \\
0 & 0 & 1-h \delta
\end{array}\right]
$$

Memiliki tiga nilai eigen dari $J_{E 0}$ berikut.

$$
\lambda 1=1+h r, \lambda 2=1-h \alpha, \lambda 3=1-h \delta
$$

Dari nilai eigen di atas, diperoleh teorema untuk titik kesetimbangan $E_{0}$ berikut.

Teorema 1. $E_{0}$ tidak stabil (saddle) karena nilai $\left|\lambda_{1}\right|$ akan selalu $>1$.

Selanjutnya, untuk titik kesetimbangan $E_{1}=(K, 0,0)$. Dengan mensubtitusi nila $E_{1}$ ke dalam matriks Jacobian $J_{E}$ diperoleh persamaan karakteristik berikut

$$
\lambda_{1}=1-h r, \lambda_{2}=1+h(K \beta-\alpha) \lambda_{3}=1+h(K c-\delta)
$$

Dari nilai eigen di atas, diperoleh teorema untuk titik kesetimbangan $E_{1}$.

Teorema 2. $E_{1}$ memiliki kestabilan sebagai berikut:

1. Jika $h<\frac{2}{r}, h<\frac{2}{\alpha-K \beta}$ untuk $K \beta<\alpha, \operatorname{dan} h<\frac{2}{\delta-K c}$ untuk $K c<\delta$, maka $E_{1}$ stabil lokal asimtotik (silk) .

2. Jika $h<\frac{2}{r}$, dan $h>\frac{2}{\alpha-K \beta}$ dan $h>\frac{2}{\delta-K c}$ atau $K \beta>\alpha$ dan $K c>\delta$, maka $E_{1}$ tidak stabil.

3. Jika $h=\frac{2}{r}$, atau $h=\frac{2}{\alpha-K \beta}$, atau $K \beta=\alpha$, atau $h=\frac{2}{\delta-K c}$, atau $K c=\delta$, maka $E_{1}$ non-hyperbolic.

Selanjutnya, untuk titik kesetimbangan $E_{2}=\left(\frac{\delta}{c}, 0, \frac{r(K c-\delta)}{K a c}\right)$. Dengan mensubtitusi nila $E_{2}$ ke dalam matriks Jacobian $J_{E}$ diperoleh persamaan karakteristik berikut

$$
F(\lambda)=\left(\lambda-a_{22}\right)\left(\lambda^{2}+p \lambda+q\right)=0
$$

Dengan $p=-\left(1-h r-\frac{2 h r \delta}{K c}-\frac{h r(K c-\delta)}{K c}+1\right)$ dan $q=\left(1-h r-\frac{2 h r \delta}{K c}-\frac{h r(K c-\delta)}{K c}\right)-$ $\left(-\frac{h a \delta}{c}\right)\left(\frac{h r(K c-\delta)}{K a}\right)$. Dari $F(\lambda)$ diperoleh satu nilai eigen $\lambda_{1}=\left(1+\frac{h \beta \delta}{c}-\frac{h r b(K c-\delta)}{K a c}\right)$

1. Jika $h<\frac{2 K a c}{K a(c \alpha-\beta \delta) b r(K c-\delta)}$ dengan $\beta \delta<c \alpha$ dan $\delta<K c$, maka $0<\lambda_{1}<$ 1.

2. Jika $h>\frac{2 K a c}{K a(c \alpha-\beta \delta)+b r(K c-\delta)}$ dengan $\beta \delta<c \alpha$ dan $\delta<K c$, maka $\lambda_{1}>1$. 
3. Jika $h=\frac{2 K a c}{K a(c \alpha-\beta \delta)+b r(K c-\delta)}$ dengan $\beta \delta<c \alpha$ dan $\delta<K c$, maka $\lambda_{1}=1$.

Selanjutnya untuk $\lambda^{2}+p \lambda+q=0$, dapat dicari berdasarkan Lemma 1. Sehingga diperoleh teorema untuk titik kesetimbangan $E_{2}$.

Teorema 3. $E_{2}$ memiliki kestabilan sebagai berikut.

1. $0<\delta<K c, \beta \delta<c \alpha . E_{2}$ stabil lokal asimtotik (silk) jika

a. $\quad h<\frac{2 K a c}{K a(c \alpha-\beta \delta)+b r(K c-\delta)}$, dan

b. $\left(2 h r \delta+h^{\wedge} 2 r \delta^{\wedge} 2\right) /\left(4+h^{\wedge} 2 r \delta\right)<K c<\delta+\frac{1}{h}$ atau jika $K c<\frac{2}{h}$ dan $K c<\delta+\frac{1}{h} \operatorname{maka} 0<\delta_{1}<\delta_{2}$.

2. $0<\delta<K c, \beta \delta<c \alpha . E_{2}$ tidak stabil jika

a. $\quad h>\frac{2 K a c}{K a(c \alpha-\beta \delta)+b r(K c-\delta)}$, atau $K c<\frac{\delta(K a \beta+b r)}{a \alpha+b r}$, dan

b. $\quad K c>\frac{2 h r \delta+h^{2} r \delta^{2}}{4+h^{2} r \delta}$ dan $K c>\delta+\frac{1}{h}$

3. $0<\delta<K c, \beta \delta<c \alpha . E_{2}$ non-hyperbolic jika

a. $h=\frac{2 K a c}{K a(c \alpha-\beta \delta)+b r(K c-\delta)}$, atau $K c=\frac{\delta(K a \beta+b r)}{a \alpha+b r}$, dan

b. $K c=\frac{2 h r \delta+h^{2} r \delta^{2}}{4+h^{2} r \delta}$ atau jika $K c<\frac{2}{h}$ dan $K c \neq \frac{h r \delta}{2}, \frac{h r \delta}{4}$ maka $0<\delta_{1}<$ $\delta_{2}$.

Selanjutnya, untuk titik kesetimbangan $E_{3}=\left(\frac{\alpha}{\beta}, \frac{r(K \beta-\alpha)}{\beta(K \beta+r)}, 0\right)$ dengan $c_{1}=\frac{c \alpha}{\beta}+$ $\frac{r K d}{K \beta+r}$ dan $c_{2}=\frac{r d \alpha}{\beta(K \beta+r)}+\delta$. Dengan mensubtitusi nilai $E_{3}$ ke dalam matriks Jacobian $J_{E}$ diperoleh persamaan karakteristik berikut

$$
F(\lambda)=\left(\lambda-\left(1+h\left(c_{1}-c_{2}\right)\right)\right)\left(\lambda^{2}+p \lambda+q\right)=0
$$

Dengan $p=-\left(2-\frac{h r \alpha}{K \beta}\right)$ dan $q=1+\frac{h^{2} r(K \beta-\alpha)-h r \alpha}{K \beta}$. Dari $F(\lambda)$ diperoleh satu nilai eigen $\lambda_{1}=1+h\left(c_{1}-c_{2}\right)$ untuk $\lambda^{2}+p \lambda+q=0$, dapat dicari berdasarkan Lemma 1. Sehingga diperoleh teorema untuk titik kesetimbangan $E_{3}$ berikut.

Teorema 4. Kestabilan $E_{3}$ adalah sebagai berikut.

1. $0<c_{1}<c_{2} . E_{3}$ stabil lokal asimtotik (silk) jika 
$h<\frac{2}{c_{2}-c_{1}}$, dan $\frac{h^{2} r \alpha^{2}+2 h r \alpha}{4+h^{2} r \alpha}<K \beta<\alpha+\frac{1}{h} \quad$ atau jika $\quad K \beta<\frac{2}{h} \quad$ maka $0<\alpha_{1}<\alpha_{2}$ dan $K \beta<\alpha+\frac{1}{h}$.

2. $E_{3}$ tidak stabil jika $h>\frac{2}{c_{2}-c_{1}}$ atau $c_{2}<c_{1}, \operatorname{dan} K \beta>\left(h^{\wedge} 2 r \alpha^{\wedge} 2+\right.$ $2 h r \alpha) /\left(4+h^{\wedge} 2 r \alpha\right)$ dan $K \beta>\alpha+\frac{1}{h}$.

3. $E_{3}$ disebut non-hyperbolic jika

$$
\begin{aligned}
& h=\frac{2}{c_{2}-c_{1}} \text { atau } c_{1}=c_{2} \text {, atau } K \beta=\frac{h^{2} r \alpha^{2}+2 h r \alpha}{4+h^{2} r \alpha} \text { atau } 0<\alpha_{1}<\alpha_{2} \text { maka } \\
& K \beta<\frac{2}{h}, K \beta \neq \frac{h r \alpha}{2}, \frac{h r \alpha}{4} .
\end{aligned}
$$

Selanjutnya, untuk titik kesetimbangan $E_{4}=\left(x, \frac{\delta-c x}{d}, \frac{\beta x-\alpha}{b}\right)$, matriks Jacobian dari persamaan (2) adalah

$$
J_{E 4}=\left[\begin{array}{ccc}
1-\frac{h r x}{K} & -\frac{h r x}{K}-h \beta x & -h a x \\
h \beta\left(\frac{\delta-c x}{d}\right) & 1 & -h b\left(\frac{\delta-c x}{d}\right) \\
h c\left(\frac{\beta x-\alpha}{b}\right) & h d\left(\frac{\beta x-\alpha}{b}\right) & 1
\end{array}\right]
$$

Diperoleh persamaan karakteristik dari $J_{E 4}$ sebagai berikut

$$
F(\lambda)=\lambda^{3}+b_{1} \lambda^{2}+b_{2} \lambda+b_{3}=0
$$

Dengan $\quad b_{1}=\frac{h r x}{K}-3, b_{2}=3-\frac{2 h r x}{K}+k_{1}+k_{2}, b_{3}=\frac{h r x}{K}-k_{1}+k_{2}+k_{3}-k_{4}-$

$1 . k_{1}=\frac{\left(h^{2} r \beta x+h^{2} K \beta^{2} x\right) l}{K d}, k_{2}=\frac{h^{2} a c x(k)}{b}, k_{3}=\frac{\left(\left(h^{3} K a d \beta x+h^{3} K b c x+h^{2} K b d\right)(-l)\right) k}{K b d}, k_{4}=$ $\frac{\left(\left(h^{3} r b d x+h^{3} K b c \beta x+h^{2} K b d\right)(-l)\right)(k)}{K b d}$. Dari $F(\lambda)$ di atas, diperoleh $F^{\prime}(\lambda)=3 \lambda^{2}+$ $b_{1} \lambda+b_{2}=0$ memiliki 2 akar persamaan $\lambda_{1,2}^{*}=\frac{-b_{1} \pm \sqrt{{b_{1}}^{2}-3 b_{2}}}{3}$ dengan $\lambda_{1,2}^{*}>0$ jika $h>\frac{3 K}{r} x$. Sehingga berdasarkan Lemma 2 , kestabilan titik $E_{4}$ dijelaskan dalam Teorema berikut.

Teorema 5. $\alpha<\beta x, c x<\delta, k_{4}<2 k_{2}+k_{3}$. $E_{4}$ memiliki kondisi sebagai berikut.

1. $E_{4}$ stabil lokal asimtotik (silk) jika $\Delta \leq 0, F(-1)<0$, dan akar $\lambda_{1,2}^{*}$ dari $F^{\prime}(\lambda)=0$ memenuhi $-1<\lambda_{1,2}^{*}<1$. 
2. $E_{4}$ non-hyperbolic jika $\Delta \leq 0$ dan $F(-1)=0$,

3. $\quad E_{4}$ tidak stabil jika tidak memenuhi Teorema 5.1 dan Teorema 5.2

\section{Simulasi Numerik}

Simulasi numerik persamaan (2) dilakukan dengan menggunakan metode Euler dengan bantuan software matematika. Nilai awal yang diguanakan untuk simulasi pada setiap titik kesetimbangan yaitu terdapat pada tabel 1 .

Tabel 1. Nilai Awal untuk Simulasi $E$

\begin{tabular}{cccc}
\hline & Nilai awal 1 & Nilai awal 2 & Nilai awal 3 \\
\hline $\mathrm{S}$ & 0,005 & 0,07 & 0,4 \\
\hline $\mathrm{I}$ & 0,006 & 0,05 & 0,1 \\
\hline $\mathrm{Y}$ & 0,004 & 0,04 & 0,5 \\
\hline
\end{tabular}

Untuk mengilustrasikan kestabilan titik kesetimbangan $E_{1}$ digunakan parameter $\quad r=5, K=10, \alpha=2,3, \beta=0,2, \delta=3,5, a=0,8, b=0,9, c=0,3$, dan $d=$ 0,25 . Ukuran langkah yang digunakan adalah $h=0,02$. Berdasarkan parameter tersebut diperoleh nilai $h r<2, h(\alpha-K \beta)<2$, dan $h(\delta-K c)$ maka syarat kestabilan $E_{1}$ terpenuhi.

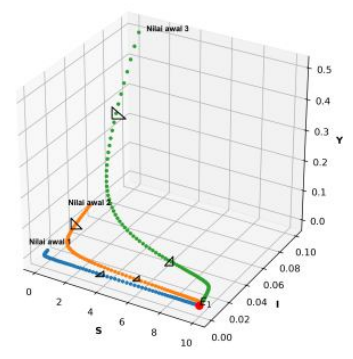

Gambar 1. Simulasi model untuk kestabilan $E_{1}$

Berdasarkan Gambar 1 terlihat bahwa $E_{1}$ stabil. Dengan diberikan tiga nilai awal, semua grafik solusi menuju titik kesetimbangan $E_{1}(10,0,0)$. Hal ini menunjukkan bahwa dalam jangka panjang predator dan prey terinfeksi akan punah dan ekosistem hanya akan dihuni oleh prey rentan.

Selanjutnya untuk mengilustrasikan kestabilan titik kesetimbangan $E_{2}$ digunakan parameter $r=1, K=10, \alpha=5, \beta=0,5, \delta=1,5, a=3, b=3,5, c=$ 0,2 , dan $d=1$. Ukuran langkah yang digunakan adalah $h=0,02$. Berdasarkan parameter tersebut diperoleh nilai $h<\frac{2 K a c}{K a(c \alpha-\beta \delta)+b r(K c-\delta)} d a n \frac{2 h r \delta+h^{2} r \delta^{2}}{4+h^{2} r \delta}<K c<$ 
$\delta+\frac{1}{h}$ maka syarat kestabilan $E_{2}$ terpenuhi.

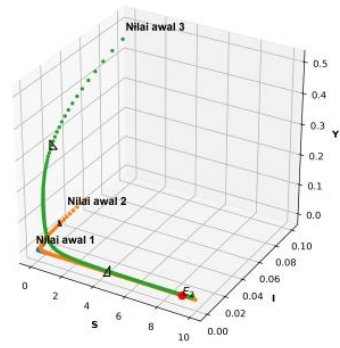

Gambar 2. Simulasi model untuk kestabilan $E_{2}$

Berdasarkan Gambar 2 terlihat bahwa $E_{2}$ stabil. Dengan diberikan tiga nilai awal, semua grafik solusi menuju titik kesetimbangan $E_{2}(7,5,0,0,083)$. Hal ini menunjukkan bahwa dalam jangka panjang prey terinfeksi akan punah dan ekosistem hanya akan dihuni oleh prey rentan dan predator.

Selanjutnya untuk mengilustrasikan kestabilan titik kesetimbangan $E_{3}$ digunakan parameter $r=1, K=10, \alpha=5, \beta=0,56, \delta=3, a=1, b=1, c=$ 0,1 dan $d=3$. Ukuran langkah yang digunakan adalah $h=0,02$. Berdasarkan parameter tersebut diperoleh nilai $h<\frac{2}{c_{2}-c_{1}}$ dan $\frac{h^{2} r \alpha^{2}+2 h r \alpha}{4+h^{2} r \alpha}<K \beta<\alpha+\frac{1}{h}$ maka syarat kestabilan $E_{3}$ terpenuhi.

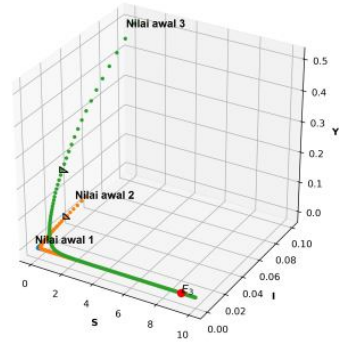

Gambar 3. Simulasi model untuk kestabilan $E_{3}$

Berdasarkan Gambar 3 terlihat bahwa $E_{3}$ stabil. Dengan diberikan tiga nilai awal, semua grafik solusi menuju titik kesetimbangan $E_{3}(5,0,45,0)$. Hal ini menunjukkan bahwa dalam jangka panjang predator akan punah dan ekosistem hanya akan dihuni oleh prey rentan dan prey terinfeksi.

Selanjutnya untuk mengilustrasikan kestabilan titik kesetimbangan $E_{4}$ digu- 
nakan parameter $r=1, K=10, \alpha=7, \beta=5, \delta=7, a=3, b=1, c=5,5$ dan $d=$ 5. Ukuran langkah yang digunakan adalah $h=0,02$. Berdasarkan parameter tersebut diperoleh nilai $\Delta \leq 0$,yaitu0 dan $F(1)<0$, yaitu -8 maka syarat kestabilan $E_{4}$ terpenuhi.

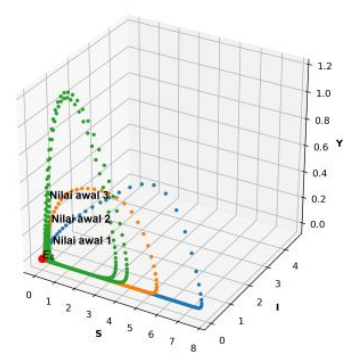

Gambar 4. Simulasi model untuk kestabilan $E_{4}$

Berdasarkan Gambar 4 terlihat bahwa $E_{4}$ stabil. Dengan diberikan tiga nilai awal, semua grafik solusi menuju titik kesetimbangan $E_{4}(1,414,0,127,0,069)$. Hal ini menunjukkan bahwa dalam jangka panjang ekosistem akan dihuni oleh prey rentan, prey terinfeksi, dan predator.

\section{Kesimpulan}

Model diskrit eko-epidemiologi diperoleh dengan melakukan diskritisasi modelmenggunakan pendekatan metode Euler. Hasil analisis menunjukkan bahwa model diskrit eko-epidemiologi terhadap kelima titik kesetimbangan, yaitu titik kesetimbangan $E_{0}$, titik kesetimbangan kepunahan prey terinfeksi dan predator $E_{1}$, titik kesetimbangan kepunahan prey terinfeksi $E_{2}$, titk kesetimbangan kepunahan predator $E_{3}$, dan titik kesetimbangan interior $E_{4}$. Titik kesetimbangan $E_{0}$ tidak pernah stabil, sedangkan sifat kestabilan titik kesetimbangan $E_{1}, E_{2}, E_{3}$ dan $E_{4}$ ditentukan oleh suatu syarat dan kondisi tertentu.

\section{Ucapan Terimakasih}

Ucapan terimakasih ditujukan kepada Bapak Hasan Panigoro, M. Si dan Ibu Emli Rahmi, M. Si yang telah banyak membantu dalam penelitian ini. 


\section{Daftar Pustaka}

Arsyad, S. H., Resmawan, R., \& Achmad, N. (2020). Analisis Model Predator-Prey Leslie-Gower dengan Pemberian Racun Pada Predator. Jurnal Riset Dan Aplikasi Matematika, 4(1), 1-16.

Brauer, F. \& Castillo-Chavez, C. (2012). Mathematical models in population biology and epidemiology. Springer, New York, second edition.

Elaydi, S. N. (2007). Discrete Chaos: With Applications in Science and Engineering, volume 2007. Chapman and Hall/ CRC, San Antonio, Texas, 2nd edition.

Fitria, V. A., \& Afiyah, N. (2017). Analisis Dinamik Skema Euler untuk Model Predator-Prey dengan efek Allee Kuadratik. Jurnal Matematika dan Pendidikan Matematika Vol. 2 No. 1 Maret 2017. DOI:10.26594/jmpm.v2i1.774.

Hasan, N., Resmawan, R., \& Rahmi, E. (2020). Analisis Kestabilan Model Eko-Epidemiologi dengan Pemanenan Konstan pada Predator. Jurnal Matematika, Statistika Dan Komputasi, 16(2), 121-142.

Hu, Z., Z. Teng., C. Jia., L. Zhang., \& X. Chen. (2014). Complex dynamical behaviors in a discrete eco-epidemiological model with disease in prey.Advances in Difference Equation, 2014:265. http:/ / doi.org/ 10.1186/ 1687-1847-2014-265.

Hu, Z., Z. Teng, T. Zhan, Q. Zhou, \& X. Chen. (2017). Globally asymtotically stable analysis in a discrete time eco-epidemiological system.Chaos, Solitions and Fractals. 99:20-31. doi:10.1016/j.chaos.2017.03.042.

Maisaroh, S., Resmawan, R., \& Rahmi, E. (2020). Analisis Kestabilan Model Predator-Prey dengan Infeksi Penyakit pada Prey dan Pemanenan Proporsional pada Predator. Jambura J. Biomath, 1(1), 8-15.

Mokodompit, R., Nurwan, N., \& Rahmi, E. (2020). Bifurkasi Periode Ganda dan Neimark-Sacker pada Model Diskret Leslie-Gower dengan Fungsi Respon Ratio-Dependent. Limits: Journal of Mathematics and Its Applications, 17(1), 19.

Munandar, A. (2017). Analisis Konsistensi dan Kestabilan Model Dinamik Diskret pada Masalah Predator-Prey dengan Fungsi Respon Ratio Dependent dan Pemanenan pada Predator. Skripsi. Universitas Islam Negeri Maulana Malik Ibrahim. Malang.

Murray, J.D. (2002). Mathematical Biology I: An Introduction. Interdisciplinary Aplied Mathematics. Springer New York, New York, NY, 3rd edition.

Purnomo, A. S., Darti, I., \& Suryanto, A. (2017). Dynamics of ecoepidemiological 
model with harvesting. AIP Conference Proceedings, 1913 (2017).

Raj, M. R. S., A. G. M. Selvam. \& R. Janagaraj. (2013). Stability in a Discrete Prey-Predator Model. International Journal of Latest Reserch in Science and Technology volume 2, Issue 1:Page No.482-485, January-February (2013).

Siddik, A. M. A. (2017). Analisis Kestabilan Model Mangsa-Pemangsa dengan Fungsi Respon Holling Tipe III dan Penyakit pada Pemangsa Super. Tesis. Universitas Hasanudin. Makassar.

Xiao, Y. \& Chen, L. (2002). A ratio-dependent predator-prey model with disease in the prey. Appl. Math. Comput. 131,397-414. 